\title{
Flekktyfus på sagatidens Island?
}

\begin{abstract}
Sammendrag
På tross av Islands isolerte geografiske beliggenhet oppsto det også der sykdomsepidemier i eldre tid. To underlige beretninger, fra henholdsvis Grettes

saga og Eyrbyggja saga - begge gjenfortalt som overnaturlige hendelser - kan muligvis være beskrivelse av en flekktyfusepidemi på sagaøya omkring år 1000 , slik en smittsom sykdom kunne forstås ut fra datidens medisinske forutsetninger. I så fall er det antakelig første gang at denne sykdommen er omtalt i medisinhistorien.
\end{abstract}

\section{Per Holck}

per.holck@medisin.uio.no

Institutt for medisinske basalfag

Avdeling for anatomi

Universitetet i Oslo

Av alle land i Europa var Island den siste nasjonen som ble befolket. Likevel er landets innvandringshistorie bedre kjent enn noen annen - Landnámabók er en unik dokumentasjon som ingen andre har maken til (1). Sagaøyas isolerte beliggenhet i forhold til det europeiske kontinent har naturlig nok hatt betydning når det gjelder utbredelsen av smittsomme sykdommer. Svartedauden, som herjet i Norge i årene 1349-50, nådde ikke Island, men en senere pestepidemi er kjent fra 1402. En krønike forteller om denne:

... Stor pestilens og sykdom over hele Island, unntatt i Vestfjordene (...) store områder avfolket. Så kom fattige folk fra Vestfjordene, gifte menn med koner og barn, for de visste at der var øde gårder nord i landet. De kunne velge den jorden der de ville slå seg ned, og mange folk fra nordlandet stammer fra dem (2).

Med en befolkning som levde spredt i små, lokale bondesamfunn, kunne man tenke seg at infeksjonssykdommer bare oppsto lokalt og nærmest forble endemiske, med få muligheter til spredning. Slik var det likevel ikke. Sagaene vitner om et folk underveis på hesteryggen, stadig på farten mellom tingstedene og de enkelte gårdene, der man kunne bli smittet og slik bringe sykdom med seg videre. Vi kjenner senere sykdomsepidemier på Island, slik som et utbrudd av kopper i 1707, der spredningen var stor. På den tiden bodde det anslagsvis 50000 mennesker på øya, og man antar at omtrent halvparten ble smittet under denne epidemien. Smittekilden skal ha vært en islandsk student som ble syk og døde i København. Eiendelene hans ble sendt til hans søster på Island, og ved kontaktsmitte ble hun og hennes omgivelser syke. Den sommeren skal rundt 17000 islendinger ha dødd av kopper (3).

Naturlig nok har vi få eller ingen kilder som gir oss informasjon om helsetilstanden i enda tidligere tider. Det lille vi vet, kommer først og fremst fra paleopatologiske studier av skjeletter som er gravd frem av arkeologer (4). Men også sagalitteraturen kan være en kilde til forståelsen av sykdom ved overgangen mellom vikingtid og kristen middelalder, selv om man neppe bør tolke tekstene bokstavelig. De ble nedskrevet et par hundre år etter at hendelsene fant sted, i høymiddelalderen, da troen og kulturen var annerledes og ikke lenger i samsvar med oppfatningene i vikingtiden.

Mens oldtidens syn på sykdom holdt seg nesten uforandret gjennom middelalderen på kontinentet, har vi i Norden få spor av antikkens medisin fra denne tiden. Her var de tradisjonelle folkemedisinske oppfatningene rådende (5). Vikingtidens og de påfølgende århundrenes syn på sykelighet var i stor grad basert på det vi ville kalle overtro, med magien som en viktig faktor i terapien. Noen få skrevne beretninger kan indirekte gi oss opplysninger om helseråd, så som enkelte runeinskripsjoner som åpenbart har vært magiske formularer rettet mot de overnaturlige kreftene som forårsaket sykdom. Faktisk betyr det norrøne runa «å utøve trolldom».

$\AA$ finne ut hvem eller hva som var årsak til sykdommen, var ofte ensbetydende med terapi og helbredelse (5). Ved at man avslørte de onde maktene, fratok man dem samtidig evnen til å skape og opprettholde sykdommen hos den enkelte. Likevel var det ikke hver manns sak å ta kampen opp mot slike krefter. Kunnskap og innsikt var nødvendig for at kuren skulle lykkes, og man måtte så å si møte maktene med deres egne våpen. Det krevde mot. Kunnskapen gikk i arv fra far til sønn. Vi finner den ikke bare i sagatekstene og i eddadiktene, men også i noen av våre folkeeventyr.

\section{Eyrbyggja saga}

Flere av de islandske sagaene synes å fortelle om utbrudd av sykdomsepidemier, men som regel overlevert forkledd som overnaturlige hendelser, ja nesten som en spøkelseshistorie.

I Eyrbyggja saga (6), som omtaler en hendelse som fant sted rundt år 1000 (siden det refereres til kristendommens innførelse), kan vi lese følgende historie:

Den sommeren da kristendommen ble innført på Island kom et skip fra Dublin inn til Snæfjellsnes på vestkysten av Island. En kvinne fra Hebridene var om bord; hun het Thorgunna. Hun slo hun seg ned på gården Frodå i Breidafjörður, og hadde kostbart utstyr med seg. Især var sengetøyet hennes så fint at ingen der omkring hadde sett maken. Frodå-bondens kone, Thurid, ble misunnelig og ville gjerne kjøpe noen av Thorgunnas saker, men fikk vite at de var ikke til salgs.

Dette var en sommer med mye regn, og en dag de holdt på med høyingen kom det en sky og la seg over gården, så det ble helt

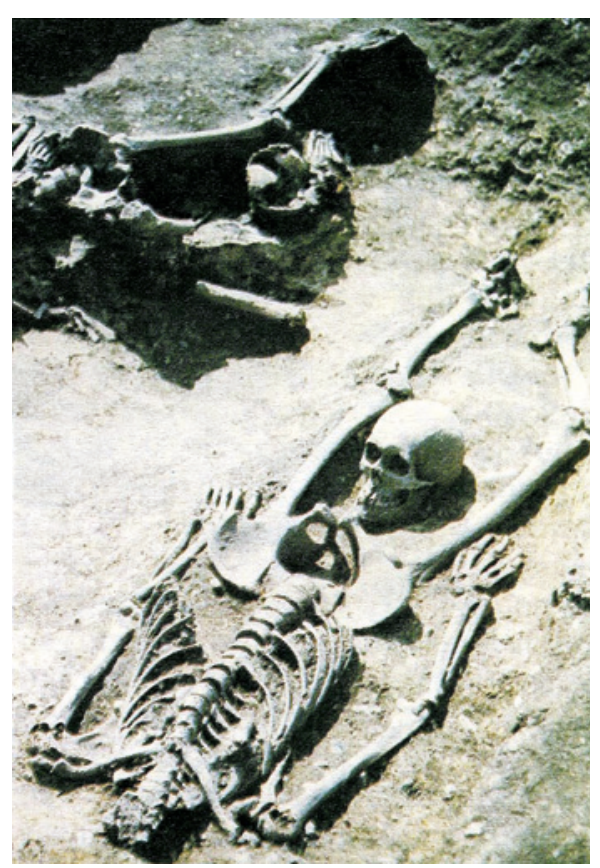

Sjællandsk begravelse fra første halvdel av 1000-tallet. Personen er halshugd og hodet lagt mellom beina. Illustrasjon fra Skalk (14) 
mørkt. Regnet fosset ned, og da det lysnet så folkene at det hadde regnet blod. Det tørket raskt, men Thorgunnas høy forble vått. Om kvelden følte hun seg dårlig, gikk hjem, tok av seg de blodige klærne og la seg til sengs med pusteproblemer. Mat ville hun ikke ha. Hun sa at det ville komme store ulykker til gården dersom folkene ikke fulgte hennes råd etter at hun var $\mathrm{død}$. Da skulle de brenne alle klærne og det fine sengetøyet hennes, og det lovet de.

Thorgunna døde etter noen dager, men Thurid syntes det var synd og skam å ødelegge de fine sakene - og beholdt dem. Men nå ble folkene på gården syke, og den ene etter den andre døde. Først døde en sauegjeter. Han ble «rar» og gikk omkring og mumlet for seg selv, og var sint og aggressiv når noen snakket til ham. En vinterkveld kom han hjem og gikk til sengs, og neste morgen var han død.

Sagaen gir et dramatisk bilde av denne karen, som nå opptrer som et ondsinnet spøkelse med overnaturlige krefter. Han skamslår en annen mann, kalt Tore trefot, som også blir syk, og går til sengs. Tore er blåsvart over hele kroppen, noe de andre på gården oppfatter som en følge av julingen han har fått av den døde sauegjeteren. «Han fikk sott av dette og døde», sier sagaen. Flere og flere dør på gården, og de opptrer post mortem som en spøkelsesbande som terroriserer hele området. Av de 30 arbeidskarene de opprinnelig hadde på Frodå døde 18 , og fem rømte sin vei.

Endelig kommer en prest til stedet. Han råder de gjenlevende folkene til å brenne det som var igjen av sakene etter Thorgunna, og etter å ha båret relikvier rundt og vasket hele huset med viet vann, ble forholdene normale igjen. «Dagen etter gikk ingen igjen på Frodå. Det var slutt med trollskapen».

\section{Grettes saga}

Den andre historien vi skal gjengi er fra Grettes saga, som antakelig forteller fra omtrent samme tid, siden sagaen omtaler kjente historiske hendelser fra tiden rundt år 1000. Der finner vi følgende beretning (7):

Den velstående bonden Thorhall, som bodde i Vatnsdal på Nord-Island, hadde en trell som het Glåm. Han arbeidet som sauegjeter på gården hans. En kveld ved juletider kom ikke Glåm hjem slik han pleide, og da folkene neste dag gikk ut $\mathrm{i}$ vinterstormen for å lete etter ham, ble han funnet



De islandske husene var trange og menneskene bodde tett innpå hverandre. Tegning av Eva Gjerde $i$ Vikingtid og rikssamling $800-1130$ (13)

død, «blåsvart og oppsvulmet». Thorhalls arbeidsfolk greide ikke å løfte ham opp og bære ham til kirke for å gravlegges, derfor røyset de ham ned der de fant ham. Ikke lenge etter ble Glåm sett som et spøkelse av de andre bøndene i nabolaget, og det ble snakket mye om dette.

Neste sommer skaffet Thorhall seg en ny sauegjeter, denne gang en kraftig kar ved navn Thorgaut, som var av utenlandsk opphav. En kveld kom heller ikke han hjem slik han pleide, og da de lette etter ham fant de ham med brukket nakke liggende på toppen av Glåms grav.

Nå døde flere av folkene på gården, den ene etter den andre, og man mente åpenbart at de var drept av Glåm.

En vinter kom Grette Åsmundsson til gårds. Han var en uredd eventyrer som hadde vært i kamp med dauinger før, og han mente nok at han skulle få en slutt på spøkeriet ved å kjempe mot Glåm. På tross av 


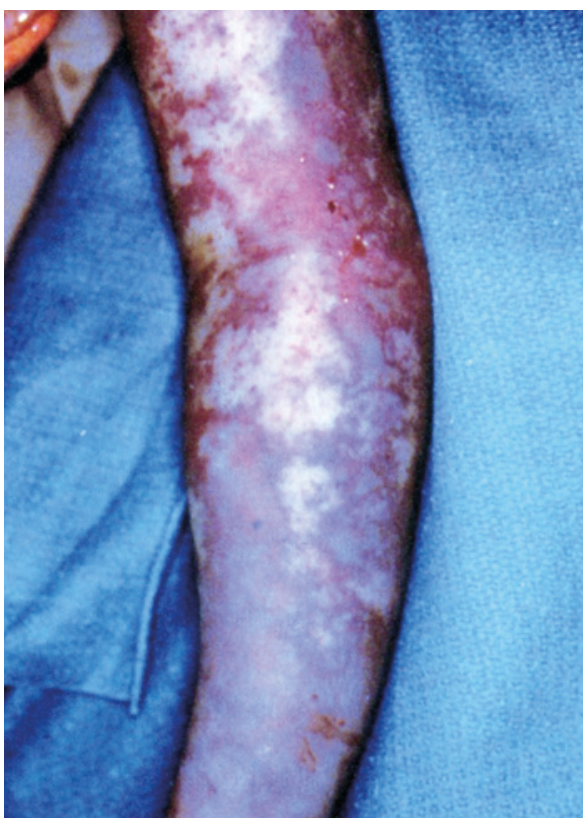

Moderne tilfelle av flekktyfus, hvor armen er blåsvart som følge av hemoragier. Fra Rubin's pathology: clinicopathologic foundations of medicine (11)

alle advarsler slo han seg ned i Vatnsdal. En natt kom Glåm til syne i skålen hvor Grette lå. De røk i hop i en voldsom kamp som endte med at Grette skar hodet av Glåm og la det mellom bena hans. Da ble det slutt på spøkeriet. For sikkerhets skyld brente de Glåm til aske som de fylte i en sekk og gravde ned, langt fra folk. Men etter dette ble Grette nesten som forandret: han ble likeglad og vanskelig å omgås, men også mørkeredd. I mørket syntes han at han så overnaturlige ting.

Vi skal her merke oss at det i juletiden dette skjer - det er da de onde maktene i åsgårdsreien er ute og farer. Dem skulle man ikke utfordre - man skulle holde seg inne, noe Grette ikke tok så nøye. Å skjære av hodet og plassere det mellom beina var åpenbart et vern mot spøkeri. Det er nevnt i Saxos krønike (8) og er også påvist et par ganger ved arkeologiske utgravninger (9).

\section{Flekktyfus?}

Dersom samtidens folkemedisinske fortolkning settes til side, kan vi ikke se bort fra at disse to dramatiske og på sin måte uhyggelige historiene beskriver en infeksjonsepidemi på Island. Mye kan tyde på at de har funnet sted på omtrent samme tid, idet
Eyrbyggja saga gir en svært presis og kontrollerbar tidsangivelse - nemlig år 1000, da kristendommen ble vedtatt på Alltinget. Også opphavet til Grettes saga kan historisk dateres til nettopp den samme tiden. Begge historiene representerer en relativt stor del av sagateksten og er vel derfor oppfattet som hendelser av betydning.

Noen sikker diagnose kan naturlig nok ikke stilles etter tusen år, men ut fra vår kunnskap kan vi tro at det muligvis dreier seg om tilfeller av flekktyfus, selv om Grettes saga er mer usikker på dette punkt. Likevel har det mange ganger vist seg at islandske sagaer er pålitelige gjenfortellere av de eldre muntlige originalene - og når det sies at Glåm var blitt blåsvart i huden dagen etter sin død og at Tore trefot hadde fått denne hudfargen allerede før han var død, så er det grunn til å se utsagnet i relasjon til en patologisk tilstand, ikke som en naturlig postmortal forandring.

Flekktyfus er en infeksjon med dødelighet opp mot $50 \%(10,11)$. Den overføres ved lusebitt og dukker opp under dårlige hygieniske forhold. Ikke minst var den kjent og fryktet under krigshandlinger i eldre tid, ofte høst og vinter når folk brukte tykke, ulne klær. Den ble også omtalt som krigstyfus, hungertyfus eller landfarsott (12)

Det er de infiserte lusenes fekalier som er smittekilden, idet de inneholder bakterien Rickettsia prowazeki. Bakterien har fătt sitt navn etter den amerikanske patologen Howard T. Ricketts (1871-1910) og den tysk-tsjekkiske bakteriologen Stanislaus (von) Prowazek (1875-1915), som begge døde etter å ha blitt smittet med flekktyfus. Smitten spres ved at man på grunn av kløe gnir fekaliene inn i bittene. Sykdommen er karakteristisk ved at kapillarene destrueres og skaper svære hemoragier i huden og indre organer - den syke er «blåsvart». Også sentralnervesystemet kan påvirkes, slik vi kan tro var tilfellet med både Grette og med sauegjeteren på Frodå.

De kjente kliniske symptomene synes å passe med sagaenes beskrivelser: Overføring av lus via klær, ofte om høsten og vinteren, feber, misfarging av huden, delirium og død. I noen tilfeller, som hos bondekona Thurid, kommer pasienten seg og overlever. Prestens vask av huset på Frodå gjorde vel sitt.

Det er fristende å tenke seg at disse to utrolige historiene kanskje er de første «beskrivelsene» av flekktyfus vi kjenner fra medisinhistorien, selv om vi ikke skal se bort fra at også andre infeksjonssykdommer vil kunne gi liknende symptomer.

\section{Per Holck (f. 1942)}

er dr.med. og professor i anatomi ved Universitetet i Oslo, med rettsantropologi som særinteresse. Han har gjennom flere år deltatt i det amerikansk-norske utgravningsteamet som har avdekket vikingtidsgården Hrisbru (www.viking.ucla.edu/mosfell_project/, hvor kirke og bygningsrester fra den aller første kristne tiden på Island - dvs. fra den tiden artikkelen omhandler - gir et godt innblikk i datidens levesett og helsetilstand.

Ingen oppgitte interessekonflikter.

\section{Litteratur}

1. Palsson H, Schei LK, red. Landnåmsboken. Beret ningen om landnåmet på Island ca. 870-930. Oslo: Fondet for Thorleif Dahls Kulturbibliotek/ Aschehoug, 1997.

2. Benedictow OJ. The Black Death 1346-1353: a complete history. Chatham: Boydell \& Brewer, 2004

3. Vasold M. Pest, Not und schwere Plagen. Seuchen und Epidemien vom Mittelalter bis heute. Augsburg: Weltbild Verlag, 1999.

4. Byock J, Walker PL, Erlandson J et al. A Vikingage valley in Iceland: the Mosfell Archaeological Project. Medieval Archaeology 2005; XLIX: 195-218.

5. Holck P. Norsk folkemedisin. Kloke koner, urtekurer og magi. Oslo: Cappelen, 1996.

6. Henriksen V, red. Norrøn saga. Bd. III. Oslo: Aschehoug, 1990.

7. Henriksen V, red. Norrøn saga. Bd. V. Oslo: Aschehoug, 1990

8. Vedel AS. Den danske krønicke: Saxo-oversættelse 1575. Faksimile udg. af Det danske Sprogog Litteraturselskab. København: Gad, 1967.

9. Holck P. En underlig gravskikk. Nicolay Arkeologisk Tidsskrift 1982; nr. 2/38: 21-2

10. Mandell G, Bennett JE, Dolin R. Mandell, Douglas, and Bennett's Priciples and practice of infectious diseases. 5. utg. Philadelphia: Elsevier, 2005.

11. Rubin R, Strayer DS. Rubin's pathology: clinicopathologic foundations of medicine. Baltimore: Lippincott Williams \& Wilkins, 2005

12. Reichborn-Kjennerud I. Vår gamle trolldomsmedisin. Bd. III. Skr. utg. av Det norske VidenskapsAkademi i Oslo. Oslo: J. Dybwad, 1940

13. Krag C. Vikingtid og rikssamling 800-1130. I: Helle $\mathrm{K}$, red. Aschehougs norgeshistorie. Bd. 2. Oslo: Aschehoug, 1995.

14. Bennike P, Christoffersen J. Et hoved kortere Skalk 1981; nr. 3: 10-3.

Mottatt 15.7. 2011, første revisjon innsendt 3.11. 2011, godkjent 10.11. 2011. Medisinsk redaktør Anne Kveim Lie. 